\title{
Toxicity effect of Auxemma oncocalyx fraction and its active principle oncocalyxone $A$ on in vitro culture of caprine secondary follicles and in vitro oocyte maturation
}

\author{
Efeito da toxicidade da fração da Auxemma oncocalyx e seu \\ princípio ativo oncocalyxona A no cultivo in vitro de folículos \\ secundários e na maturação in vitro de oócitos de caprinos
}

\author{
Johanna Leiva-Revilla $^{1 *}$; Jesús Cadenas ${ }^{1}$; Luis Alberto Vieira ${ }^{1}$; \\ Claudio Cabral Campello²; Juliana Jales de Hollanda Celestino ${ }^{3}$; \\ Otília Deusdênia Loiola Pessoa ${ }^{2}$; Gary Allen Apgar ${ }^{4}$; \\ Ana Paula Ribeiro Rodrigues²; José Ricardo de Figueiredo²; Carolina Maside ${ }^{2}$
}

\begin{abstract}
The extract of Auxemma oncocalyx (A. oncocalyx) and its main component, oncocalyxone A (onco A), possess anti-tumoral activity that may affect fertility. There is limited literature on the action of these substances regarding caprine folliculogenesis. In this study, we evaluated the effect of $A$. oncocaly and onco A on the in vitro culture of isolated secondary follicles (Experiment 1 ) and on the in vitro maturation (IVM) of oocytes from caprine antral follicles grown in vivo (Experiment 2). Isolated secondary follicles were distributed in six groups: the non-cultured control was immediately fixed in $4 \%$ paraformaldehyde. The remaining follicles were cultured for 7 days in $\alpha$-minimal essential medium $\left(\alpha-\mathrm{MEM}^{+}\right)$alone (control) or with dimethyl sulfoxide (DMSO), doxorubicin (DXR), A. oncocalyx, or onco A. After culture, the follicles were evaluated for antrum formation, growth rate, apoptosis (TUNEL), cellular proliferation (PCNA), as well as the expression of $B C L 2$ and $B A X$. In addition, cumulus oocyte complexes (COCs) were aspirated and allocated into five treatments for IVM: control, cultured only in maturation base medium (TCM 199'); or supplemented with DMSO; DXR; A. oncocalyx or onco A. After IVM, oocyte chromatin configuration and viability were assessed. After 7 days of culture, a reduction was noted in the percent of morphologically intact follicles, antrum formation, growth rate, and numbers of PCNApositive granulosa cells $(\mathrm{P}<0.05)$. After culture, the DXR treatment showed a higher percent of TUNELpositive follicles and relative BAX:BCL2 mRNA ratio's ( $\mathrm{P}<0.05)$. After IVM of the COCs, DXR, $A$. oncocalyx, and onco A treatments showed a greater percent $(\mathrm{P}<0.05)$ of abnormal oocytes and a lower percent of viable oocytes as compared with the control group $(\mathrm{P}<0.05)$. However, only DXR and onco A treatments increased the percent of alive oocytes with abnormal chromatin configuration $(\mathrm{P}<0.05)$. There were no differences in the maturation rates among the control group and DXR, A. oncocalyx, and onco A treatments. In conclusion, under our culture conditions, A. oncocalyx and onco A did not exhibit toxic effect on isolated secondary follicles and on maturation rates of COCs recovered from antral follicles. However, these substances negatively affected the oocyte viability. Thus, culture methods including in vitro secondary follicle culture and in vitro oocyte maturation toxicity test are appropriate methods to evaluate the possible effects of drugs on folliculogenesis.
\end{abstract}

Key words: Auxemma oncocalyx. Doxorubicin. Oncocalyxone A. Folliculogenesis. Oocytes.

\footnotetext{
${ }^{1}$ Pesquisadores, Universidade Estadual do Ceará, UECE, Fortaleza, CE, Brasil. E-mail: johileiva@gmail.com; j.cadenasmoreno@ gmail.com; tuncan24@yahoo.es

2 Profs., UECE, Fortaleza, CE, Brasil. E-mail: cccampello@yahoo.com.br; otilialoiola@gmail.com; anapaula.ribeirorodrigues@ gmail.com; figueiredo.lamofopa@gmail.com; carolinamaside@gmail.com

${ }^{3}$ Prof ${ }^{a}$, Universidade da Integração Internacional da Lusofonia Afro-Brasileira, UNILAB, Acarape, CE, Brasil. E-mail: juliana. celestino@unilab.edu.br

${ }^{4}$ Prof., Southern Illinois University-Carbondale, SIU, Illinois, USA. E-mail: pigguy@siu.edu

* Author for correspondence
} 


\section{Resumo}

O extrato da Auxemma oncocalyx (A. oncocalyx) e seu componente, Oncocalyxona A (onco A), possui atividade antitumoral, podendo afetar a fertilidade. Entretanto, estudos sobre a ação dessas substâncias em relação à foliculogênese caprina são desconhecidos. $\mathrm{O}$ objetivo desse estudo foi avaliar o efeito da A. oncocalyx e onco A no cultivo in vitro de folículos secundários isolados (Experimento 1) e na maturação in vitro (MIV) de oócitos de folículos antrais caprinos crescidos in vivo (Experimento 2). Folículos secundários isolados foram distribuídos em seis grupos, em que o controle não-cultivado foi imediatamente fixado em paraformaldeído $4 \%$. Os folículos restantes foram cultivados durante 7 dias em $\alpha-\mathrm{MEM}^{+}$sozinho (controle) ou suplementado com DMSO, doxorrubicina (DXR), A. oncocalyx ou onco A. Após o cultivo, os folículos foram avaliados quanto à formação de antro, taxa de crescimento, apoptose (TUNEL) e proliferação celular (PCNA), bem como a expressão dos genes BCL2 e BAX. Além disso, os complexos cumulus-oócitos (CCOs) foram aspirados e distribuídos em cinco tratamentos para MIV: o controle em meio de maturação (TCM 199+), e os demais tratamentos suplementados com DMSO, DXR, A. oncocalyx ou onco A. Depois da MIV, a configuração da cromatina e viabilidade oocitária foram avaliadas. Após 7 dias de cultivo, observou-se redução na percentagem de folículos morfologicamente intactos, na formação de antro, na taxa de crescimento e no número de células PCNA positivas $(\mathrm{P}<0,05)$. Depois do cultivo, no tratamento DXR foi observada maior percentagem de folículos TUNEL positivos $(\mathrm{P}<0,05)$ e também aumento na taxa de RNAm BAX: BCL2 $(\mathrm{P}<0,05)$. Após MIV dos CCOs, nos tratamentos com DXR, A. oncocalyx e onco A, observou-se maior $(\mathrm{P}<0,05)$ percentagem de oócitos anormais e menor de oócitos viáveis quando comparados ao grupo controle ( $\mathrm{P}$ $<0,05)$. No entanto, apenas nos tratamentos DXR e onco A aumentou a percentagem de oócitos viáveis com configuração da cromatina anormais $(\mathrm{P}<0,05)$. Não houve diferenças nas taxas de maturação entre o grupo controle e os tratamentos DXR, A. oncocalyx e onco A. De acordo com nossas condições de cultivo, pode-se concluir que a $A$. oncocalyx e onco A não apresentaram efeitos tóxicos sobre folículos secundários isolados e as taxas de maturação dos CCOs recuperados a partir de folículos antrais. No entanto, estas substâncias afetam negativamente a viabilidade oocitária. Assim, o uso de biotecnologias como o cultivo de folículos secundários in vitro e MIV de oócitos para testes de toxicidade são métodos apropriados para avaliar possíveis efeitos das drogas na foliculogênese.

Palavras-chave: Auxemma oncocalyx. Doxorubicina. Oncocalyxona A. Foliculogénesis. Ovócitos

\section{Introduction}

In vitro manipulation of oocytes enclosed in preantral follicles is used in drug toxicity testing to avoid the ethical concerns and restrictions of in vivo experiments. Alternatively, the utilization of in vitro preantral follicle culture has been proposed as a safe method to study the effects of drugs on reproduction. This technique enables the testing of beneficial or toxic effects on ovarian follicles in vitro before their application in experiments involving live subjects (FIGUEIREDO et al., 2011).

Cancer research continuously seek the development and discovery of new treatment options (CRAGG et al., 2014). Numerous drugs used in cancer chemotherapy exhibit genotoxic, carcinogenic, and teratogenic effects on normal cells as well. Doxorubicin (DXR) is one of the most commonly used drug (OKTEM; OKTAY, 2007 ) in the treatment of cancers of bladder, breast, lung, ovary, and other organs (CHOW et al., 2010); this drug transgresses the cell membrane and accumulates in both the nucleus mitochondria by inducing oxidative stress and chromosomal obliteration through the inhibition of topoisomerase II (MAILER; PETIRING, 1976). However, DXR induces ovarian toxicity by reducing the ovulation rate along with reducing the size of the ovary among other side effects (OKTEM; OKTAY, 2007; BARJOSEPH et al., 2010; BEN-AHARON et al., 2010). The poor specificity of these drugs against tumor tissue highlights the need for developing new drugs with fewer side effects (OKTEM; OKTAY, 2007) and more specificity. 
Plants are excellent sources of raw material when searching for new drugs, and they are commonly used in the treatment of cancer (GRAHAM et al., 2000). Moreover, over $60 \%$ of currently used anti-cancer agents are derived from natural sources including plants, marine organisms, and micro-organisms (NEWMAN et al., 2003; CRAGG; NEWMAN, 2005). Auxemma oncocalyx (A. oncocalyx) is a common tree found in the state of Ceará in Northeast Brazil (BRAGA, 1976). It has been widely used in folk medicine as an adjunctive treatment for injuries (BRAGA, 1976; FERREIRA et al., 2003). Some studies have attributed biological activities such as analgesic, anti-oxidant, anti-tumor, and antiinflammatory effects to this plant (PESSOA et al., 1992; LINO et al., 1996; FERREIRA et al., 2003, 2004). Oncocalyxone A (onco A) isolated from the stem heartwood of the plant has demonstrated high antioxidant activity (FERREIRA et al., 2003) and an antiproliferative effects on tumor cell cultures (COSTA-LOTUFO et al., 2002).

Past studies have suggested that onco $\mathrm{A}$ is a possible anticancer compound with antitumor and cytotoxic activities on human leukemia cells and other cell cancer lines, but without genotoxicity (LEYVA et al., 2000; PESSOA et al., 2003, 2004. However, the effect of A. oncocalyx and onco A on in vitro folliculogenesis remains unknown.

Hence, in this study, we aimed to investigate the effects of $A$. oncocalyx and onco A on the in vitro survival and growth of isolated goat secondary follicles (Experiment 1) as well as on the viability and nuclear maturation of oocytes recovered from antral follicles (Experiment 2).

\section{Materials and Methods}

\section{Source of ovaries}

Ovaries $(n=130)$ from 65 cycled, mixed breed adult goats with a body condition score of 3 (30 and 35 for experiments 1 and 2, respectively) were obtained from a local slaughterhouse in Mossoro,
Rio Grande do Norte state (northeast region, $05^{\circ} 11^{\prime} 15^{\prime \prime} \mathrm{S}$ and $\left.37^{\circ} 20^{\prime} 39^{\prime \prime} \mathrm{W}\right)$. The ovaries were washed in $70 \%$ alcohol for approximately $10 \mathrm{~s}$ and then twice in minimal essential medium (MEM) supplemented with $100 \mu \mathrm{g} / \mathrm{mL}$ penicillin and 100 $\mu \mathrm{g} / \mathrm{mL}$ streptomycin plus HEPES (MEM-HEPES). The ovaries were transported to the laboratory at 4 or $33^{\circ} \mathrm{C}$ (experiments 1 or 2 , respectively) in a thermal container within $4 \mathrm{~h}$ of removal. All chemicals used were purchased from Sigma Chemical Co. (St. Louis, MO, USA), unless otherwise indicated.

\section{Extracting onco A from A. oncocalyx}

A. oncocalyx was collected in August 2012 at Acarape (state of Ceará) in Northeast Brazil. The plant was identified by Dr. Maria Iracema B. Loiola of the Department of Biology of Federal University of Ceará. A voucher specimen (No. 18459) was deposited in the Herbarium Prisco Bezerra (EAC), Federal University of Ceará.

The air-dried and powdered heartwood $(2.5 \mathrm{~kg})$ of $A$. oncocalyx was extracted with $\mathrm{EtOH}$ ( $2 \mathrm{x}$ each) at room temperature. The combined extracts were evaporated under reduced pressure to yield the crude extract $(100 \mathrm{~g})$ that was then fractionated over silica gel and eluted with $\mathrm{CH}_{2} \mathrm{Cl}_{2}, \mathrm{CH}_{2} \mathrm{Cl}_{2} /$ EtOAc (7:3 and 1:1), EtOAc, EtOAc/MeOH (9.5:0.5 and 1:1) to yield after solvent evaporation the correspondent fractions: $6.60,5.99,8.01,3.36,50.08$, and 25.96 g, respectively. The fraction EtOAc/MeOH 9.5:0.5 $(50.0 \mathrm{~g})$ was subjected to a silica gel $(200 \mathrm{~g})$ chromatography column using $\mathrm{CH}_{2} \mathrm{Cl}_{2} /$ EtOAc 1:1 (200 mL), 7:3 (500 mL), EtOAc (1000 mL), and EtOAc/ MeOH 9.5:0.5 (400 mL) to yield 60 fractions of approximately $30 \mathrm{~mL}$ each. After comparative analysis by thin-layer chromatography (TLC), these fractions were pooled into 3 main fractions: F1 (1-20; $8.2 \mathrm{~g})$, F2 (21-54; $25.2 \mathrm{~g})$, and F3 (55-60; 16.7 g). F2 (21-54; 25.2 g) was subjected to chromatography twice over silica gel eluted with $\mathrm{CH}_{2} \mathrm{Cl}_{2} /$ EtOAc 1:1, 7:3, EtOAc, EtOAc/ $\mathrm{MeOH}$ (9.5:0.5), and $\mathrm{MeOH}$. Fractions $\mathrm{CH}_{2} \mathrm{Cl}_{2} /$ 
EtOAc (7:3) and EtOAc yielded a dark solid, which was purified by filtration with acetone. The resultant material $(5.5 \mathrm{~g})$ was a deep-red powder (mp 207-208 ${ }^{\circ}$ identified as rel-8a-hydroxy-5hydroxymethyl-2-methoxy-8ab-methyl-7,8,8a,9tetrahydro-1,4-anthracenedione (named onco A), as previously described by PESSOA et al. (1993).

${ }^{1} \mathrm{H}$ NMR (200 MHz, DMSO-d $): 6.00$ (s, H-3), 6.03 (br d, H-6), 2.52 (br d, J 17.2 Hz, H-7eq), 2.60 (dd, J 17.2, 3.9 Hz, H-7ax), 3.57 (br s, H-8), 2.90 (d, $J 18.4 \mathrm{~Hz}, \mathrm{H}-9 \mathrm{ax}), 2.34$ (d, $J 18.4 \mathrm{~Hz}, \mathrm{H}-9 \mathrm{eq}$ ), 6.50 (s, H-10), 4.16 (br s, 2H-11), 0.74 (s, 3H-12), 3.78 (s, OMe). ${ }^{13} \mathrm{C}$ NMR (50.3 MHz, DMSO- $\left.d_{6}\right)$ : 181.2 (C-1), 159.8 (C-2), 106.4 (C-3), 186.1 (C-4), 134.6 (C-4a), 146.7 (C-5), 128.4 (C-6), 32.0 (C-7), 70.1 (C-8), 38.9 (C-8a), 29.2 (C-9), 133.0 (C-9a), 111.8 (C-10), 135.5 (C-10a), 61.6 (C-11), 21.3 (C12), 56.7 (OMe).

Notably, the fraction of $A$. oncocalyx contained $80 \%$ of onco A (FERREIRA et al., 2004), therefore the concentration of $A$. oncocalyx was in equal proportion of onco A. A. oncocalyx and onco A were diluted with dimethyl sulfoxide (DMSO) as a vehicle. The concentrations of $A$. oncocalyx and onco A were selected based on previous studies performed in our laboratory (LEIVA-REVILLA et al., 2016).

\section{Experimental design}

For Experiment 1, isolated secondary follicles were randomly distributed in the following six treatments: I) non-cultured control; II) cultured in $\alpha-\mathrm{MEM}^{+}$(control); III) $\alpha-\mathrm{MEM}^{+}$supplemented with $20 \% \mathrm{v} / \mathrm{v}$ DMSO; IV) $\alpha$-MEM ${ }^{+}$supplemented with $0.3 \mu \mathrm{g} / \mathrm{mL}$ DXR (positive toxicity control); V) $\alpha$-MEM ${ }^{+}$supplemented with $1.2 \mu \mathrm{g} / \mathrm{mL} A$. oncocalyx, or VI) $\alpha$-MEM ${ }^{+}$supplemented with 1 $\mu \mathrm{g} / \mathrm{mL}$ onco A. The culture was replicated seven times, and a total of 60 follicles (at least) were used in each treatment. Cultured follicles were evaluated for antrum-formation capacity, growth rate, apoptosis (terminal deoxynucleotidyl transferase- mediated dUTP biotin nick end labeling; TUNEL), and cellular proliferation (proliferating cell nuclear antigen; PCNA). In addition, both non-cultured and cultured isolated secondary follicles from the five treatments after culture were selected for $B c l 2$ and Bax expression.

For experiment 2, cumulus oocyte complexes (COCs) were allocated into five treatments to perform in vitro maturation: I) TCM-199+ (control), II) $\mathrm{TCM}-199^{+}$supplemented with $20 \% \mathrm{v} / \mathrm{v} \mathrm{DMSO}$, III) $\mathrm{TCM}^{-199^{+}}$supplemented with $0.3 \mu \mathrm{g} / \mathrm{mL}$ DXR, IV) TCM-199+ supplemented with $1.2 \mu \mathrm{g} /$ $\mathrm{mL}$ A. oncocalyx, or V) TCM-199+ supplemented with $1 \mu \mathrm{g} / \mathrm{mL}$ onco A. The culture (maturation) was replicated three times, and a total of 75 (at least) COCs were used in each treatment. After 24 $\mathrm{h}$ of in vitro maturation (IVM), oocyte chromatin configuration and viability were assessed by fluorescence microscopy.

Isolation, selection and culture of secondary follicles

After transportation, the fat and connective tissue surrounding the ovaries were removed. Cortical slices (1-2-mm thick) were cut by a surgical blade (under sterile conditions) and placed in a holding medium containing HEPES-MEM. Secondary follicles of approximately $200-\mu \mathrm{m}$ diameter were visualized under stereomicroscope (SMZ 645; Nikon, Tokyo, Japan) equipped with ocular micrometer (100X magnification) and manually dissected from strips of ovarian cortex using 26-gauge (26 G) needles. After isolation, the follicles were transferred to $100-\mu \mathrm{L}$-drops-containing fresh culture medium under mineral oil for further evaluation of follicular quality. Follicles with a visible and centrally located oocyte surrounded by granulosa cells and an intact basement membrane with no antrum formation were selected as secondary follicles for further culture.

The selected follicles were individually cultured in $100 \mu \mathrm{L}$ drops of culture media and allocated into different treatments $(67,58,59,59$, and 
58, respectively, for control, DMSO, DXR, $A$. oncocalyx, and onco A treatments) described further in the experimental design (item 2.5). The base culture media of $\alpha$-MEM was supplemented with $3 \mathrm{mg} / \mathrm{mL}$ bovine serum albumin (BSA), $10 \mathrm{ng} / \mathrm{mL}$ insulin, $5.5 \mu \mathrm{g} / \mathrm{mL}$ transferrin, $5 \mathrm{ng} / \mathrm{mL}$ selenium, $2 \mathrm{mM}$ glutamine, $2 \mathrm{mM}$ hypoxanthine, $50 \mu \mathrm{g} / \mathrm{mL}$ ascorbic acid, and $100 \mathrm{ng} / \mathrm{mL}$ FSH $\left(\alpha-\mathrm{MEM}^{+}\right)$. The culture was performed at $39^{\circ} \mathrm{C}$ under $5 \%$ $\mathrm{CO}_{2}$ atmosphere in air for 7 days. Fresh media were prepared and pre-equilibrated for $2 \mathrm{~h}$ prior to use. Every alternate day, $60 \mu \mathrm{L}$ of medium were replenished in each drop.

\section{Assessment of follicle development}

During culture, the follicles were classified according to their morphology. Follicles showing dark oocytes and surrounding cumulus cells or those with mis-shapen oocytes were classified as degenerated. At day 7 of culture, follicular diameter and antrum formation were evaluated only in healthy follicles. The follicular diameter was determined as the mean of two perpendicular measures of each follicle by using an ocular micrometer (100X magnification) inserted into the stereomicroscope (SMZ 645). Antrum formation was defined as a visible translucent cavity within the granulosa cell layers.

\section{Assessment of apoptosis by TUNEL assay}

For determination of DNA fragmentation, a TUNEL detection kit (R\&D Systems; Minneapolis, MN, USA) was used as per the manufacturer instructions. The follicles were fixed in $4 \%$ paraformaldehyde buffered with PBS. Subsequently, the blocks were sectioned into $5-\mu \mathrm{m}$ thick sections following de-paraffinization and boiled for antigen retrieval in $0.01 \mathrm{M}$ citric acid. The blockade of exogenous peroxidase and nonspecific blocking were performed in a humid chamber. The incubation of TUNEL consisted of the addition of a TUNEL mixture for $1 \mathrm{~h}$ at $37^{\circ} \mathrm{C}$ (moist chamber), and, after washing, $50 \mathrm{~mL}$ Convert POD was added for $30 \mathrm{~min}$ at $37^{\circ} \mathrm{C}$ (moist chamber). Follicles were considered TUNEL-positive when the oocyte nucleus was stained brown.

\section{PCNA assessment}

Follicles were fixed in 4\% paraformaldehyde and $5-\mu \mathrm{m}$ paraffin sections were mounted under microscope slides. The paraffin sections were heated at $65^{\circ} \mathrm{C}$ for $45 \mathrm{~min}$. Following de-paraffinization, the sections were rehydrated in a series of graded ethanol/water solutions and then boiled in $0.01 \mathrm{M}$ citric acid (pH 6.0) at $95-100{ }^{\circ} \mathrm{C}$ for $5 \mathrm{~min}$, followed by incubation in $3 \%$ hydrogen peroxide $\left(\mathrm{H}_{2} \mathrm{O}_{2}\right)$ for $10 \mathrm{~min}$. The tissues were blocked with avidin and biotin and incubated with Rb Pab-PCNA (1:30002426 Abcam) overnight at $4^{\circ} \mathrm{C}$. After rinsing thoroughly with PBS, the sections were incubated with caprine pAB-Rb IgG antibody (Biotin) for 30 min at room temperature. The PCNA expression was detected by the reaction of peroxidase with 3,39-diaminobenzidine tetrahydrochloride (DAB) and analyzed under a light microscope (400X magnification; Eclipse E200, Nikon). PCNA assessment was evaluated by counting positive cells/total cells for each follicle to obtain an index of positive cells. A total of 34-427 granulosa cells per follicle were evaluated.

\section{Quantitative real-time PCR analysis for BAX, BCL2} in isolated secondary follicles

For RNA isolation, three pools of 10 isolated secondary follicles were collected from each experimental group after 7 days of culture (Experiment 1). The samples were stored in microcentrifuge tubes $(1.5 \mathrm{~mL})$ with $100-\mu \mathrm{L}$ Trizol at $-80^{\circ} \mathrm{C}$. Total RNA from follicles were isolated and purified with the Trizol ${ }^{\circledR}$ Plus Purification Kit (Invitrogen; São Paulo, Brazil). The RNA preparations were treated with DNase I and the Pure 
Link RNA Mini Kit (Invitrogen). Complementary DNA (cDNA) was synthesized from the isolated RNA using Superscript II RNase H-Reverse Transcriptase (Invitrogen). The qPCR reaction was performed in a final volume of $20 \mu \mathrm{L}$, containing $1 \mu \mathrm{L}$ of each cDNA, $1 x$ Power SYBR Green PCR Master Mix (10 $\mu \mathrm{L})$ (PE Applied Biosystems; Foster City, CA, USA), $5.5 \mu \mathrm{L}$ of ultrapure water, and $0.5 \mu \mathrm{M}$ of both sense and anti-sense primers. The gene-specific primers used for the amplification of different transcripts are listed in Table 1. Transcript levels in follicular cells were normalized to the content of peptidylprolyl Isomerase A (PPIA) and glyceraldehyde-3-phosphate-dehydrogenase
(GAPDH). Primer specificity and amplification efficiency were verified for each gene. The qPCR cycling conditions included an initial denaturation and polymerase activation step at $94^{\circ} \mathrm{C}$ for $15 \mathrm{~min}$, followed by 40 cycles of $15 \mathrm{~s}$ at $94^{\circ} \mathrm{C}, 30 \mathrm{~s}$ at $60^{\circ} \mathrm{C}$, and $45 \mathrm{~s}$ at $72^{\circ} \mathrm{C}$, followed by a final extension step for $10 \mathrm{~min}$ at $72^{\circ} \mathrm{C}$. After amplification, melting curve analysis was performed between $60^{\circ} \mathrm{C}$ and $95^{\circ} \mathrm{C}$ for all genes. All amplifications were conducted in the Bio-Rad iQ5 (Hercules; CA, USA). The delta-deltaCT method was used to transform threshold cycle values into normalized relative expression levels (LIVAK; SCHMITTGEN, 2001)

Table 1. Oligonucleotide primers used for PCR analysis of goat secondary follicles.

\begin{tabular}{|c|c|c|c|}
\hline Target gene & Primer sequence $\left(5^{\prime} \rightarrow 3^{\prime}\right)$ & $\begin{array}{c}\text { Sense (S) } \\
\text { Antisense (AS) }\end{array}$ & Genbank accession nos. \\
\hline \multirow{2}{*}{ GAPDH } & ATGCCTCCTGCACCACCA & $\mathrm{S}$ & GI: 298676424 \\
\hline & AGTCCCTCCACGATGCCAA & AS & (Ovis aries) \\
\hline \multirow{2}{*}{ PPIA } & TCATTTGCACTGCCAAGACTG & $\mathrm{S}$ & GI:548463626 \\
\hline & TCATGCCCTCTTTCACTTTGC & AS & (Capra hircus) \\
\hline \multirow{2}{*}{$B A X$} & TTTTGCTTCAGGGTTTCATCCAGGA & $\mathrm{S}$ & GI:926714830 \\
\hline & CAGCTGCGATCATCCTCTGCAG & AS & (Capra hircus) \\
\hline \multirow{2}{*}{$B C L 2$} & GTTTTCCGACGGCAACTTC & $\mathrm{S}$ & GI:354549710 \\
\hline & GGATGGTCCTGATCAACTCG & AS & (Capra hircus) \\
\hline
\end{tabular}

In vitro maturation of caprine oocytes recovered from antral follicles

In the laboratory, approximately 399 COCs from 70 ovaries were collected by slicing ovaries. Oocytes with a compact cumulus mass and a dark, evenly granulated cytoplasm were selected for IVM and washed three times in base maturation medium (TCM-199+) consisting of TCM-199 supplemented with $1 \mu \mathrm{g} / \mathrm{mL} 17 \beta$-estradiol, $5 \mu \mathrm{g} / \mathrm{mL}$ LH, $0.5 \mu \mathrm{g} /$ $\mathrm{mL} \mathrm{rFSH}, 10 \mathrm{ng} / \mathrm{mL}$ EGF, $1 \mathrm{mg} / \mathrm{mL}$ BSA, $22 \mu \mathrm{g} /$ $\mathrm{mL}$ pyruvate, $50 \mathrm{ng} / \mathrm{mL}$ IGF-I, and $100 \mu \mathrm{mol} / \mathrm{L}$ cysteamine, previously pre-equilibrated at $39^{\circ} \mathrm{C}$ and $5 \% \mathrm{CO}_{2}$ in air. Groups of COCs were cultured in $500 \mu \mathrm{L}$ of designed media into each well of a 4-well multidish (Nunc; Roskilde, Denmark) for $24 \mathrm{~h}$ at $39^{\circ} \mathrm{C}$ in $5 \% \mathrm{CO}_{2}$.
Assessment of oocyte chromatin configuration and viability

Following maturation, the COCs were denuded mechanically, and the oocytes were washed in PBS and then incubated in $100 \mu \mathrm{L}$ droplets containing $4 \mu \mathrm{M}$ calcein-AM, $2 \mu \mathrm{M}$ ethidium homodimer-1 (Molecular Probes; Invitrogen, Karlsruhe, Germany), $0.5 \%$ of glutaraldehyde, and $10 \mu \mathrm{M}$ of Hoechst 33342 for $30 \mathrm{~min}$.

The chromatin configuration was assessed by fluorescence microscopy (Eclipse 80i; Nikon), and classified as abnormal chromatin configuration when the nucleus was pyknotic, compact, or in a strange configuration; and normal chromatin configuration was considered when the nucleus was 
in germinal vesicle $(\mathrm{GV})$ or meiotic resumption. Meiotic resumption was defined as the state when the nucleus was in germinal vesicle break down (GVBD), metaphase I (MI), or in metaphase II (MII) stages. Thereafter, oocytes were examined under fluorescence microscope (Eclipse 80i; Nikon) for the evaluation of live/dead fluorescent staining. The emitted fluorescent signals of calcein-AM and ethidium homodimer-1 were collected at 488 and $568 \mathrm{~nm}$, respectively. Oocytes were considered alive when the cytoplasm was stained positively with calcein-AM (green) and the chromatin was not labeled with ethidium homodimer-1 (red). Moreover, oocytes were classified as viable when the cytoplasm was stained positively with calcein-AM and they showed a normal chromatin configuration, as mentioned above. Moreover, abnormal oocytes were of three types: i) oocytes stained positively with calcein-AM with abnormal chromatin were considered as alive with abnormal chromatin configuration, ii) oocytes unstained with calcein-AM and stained with ethidium homodimer were considered as non-alive, and iii) non-alive plus alive with abnormal chromatin configuration formed the total number of abnormal oocytes.

\section{Statistical analyses}

For both the experiments, data referring to continuous variables were initially evaluated for homoscedasticity and normal distribution of the residues by Bartlett's and Shapiro-Wilk tests, respectively. For confirmation, both requirements underlying analysis of variance was performed considering a completely randomized design in a factorial arrangement of $5 \times 2$ (five treatments and two times of culture). When any main effect or their interactions were significant, comparisons were further analyzed by Student-Newman-Keuls test, and the results were expressed as mean \pm standard deviation. When heteroscedasticity was observed, even after transformation of data, non-parametric Kruskal-Wallis test was applied. Data for discrete variables were analyzed by chi-square test (or Fisher Exact Test when $\mathrm{n}<5$ ), and the results were expressed as percent. In all cases, a probability of $\mathrm{P}$ $<0.05$ indicated a significant difference.

\section{Results and Discussion}

For the first time, in the present study, reproductive toxicity of in vitro-cultured isolated follicles and in vitro-matured COC's were used to assess the toxicity of $A$. oncocalyx and its isolated compound onco A. Various toxicological tests are available to investigate the effects of different drugs on folliculogenesis. However, in vitro cultures have become a tool to analyze the effects of several components on the survival, growth, and maturation of follicles in different animal models (STEFANSDOTTIR et al., 2014). In vitro experiments are of great importance as they provide appropriate information about the effect of different compounds before in vivo testing. The in vitro culture of caprine preantral follicles and the IVM of COCs were found to be appropriate techniques for analyzing the effect of drugs on folliculogenesis.

A total of 301 secondary follicles were analyzed before and after in vitro culture in different treatment set-ups (Figure 1). The effects of the treatments on the percent of morphologically intact follicles and antrum formation are shown (Table 2). After 7 days of culture, a lower $(\mathrm{P}<$ 0.05 ) percent of morphologically intact follicles and antrum formation was noted in DXR treatment as compared to that in other treatments (control, DMSO, A. oncocalyx, and onco A). Follicular diameter and growth rate of follicles after 7 days of in vitro culture are shown in Table 3. A significant increase was noted in the follicular diameter from D0 to D7 in all treatments, except for onco A and DXR treatments. In addition, DXR significantly reduced the growth rate when compared to the other treatments (control, DMSO, A. oncocalyx, and onco A). The in vitro follicle culture system used in the present study was effective to investigate the 
impact of the studied drugs (DXR, A. oncocalyx, and onco A) on in vitro folliculogenesis. The control medium ensured the maintenance of appropriate rates of follicle survival (92.54\%), growth (4.19 \pm $6.12)$, and antrum formation $(59.70 \%)$. These data are in agreement with those of previous studies reporting in vitro culture of caprine preantral follicles for 6 days using the same culture medium (ARAÚJO et al., 2011; DUARTE et al., 2013). In this study, A. oncocalyx and onco A did not alter the folliculogenesis parameters such as survival, antrum formation, and growth rate. On the contrary, DXR had a toxic effect on all these folliculogenesis end-points. A. oncocalyx and onco A were less harmful to in vitro secondary follicles than DXR, although both drugs were able to maintain follicular morphology without affecting either the antrum formation or the follicular growth. Both onco A and DXR are known to have anti-carcinogenic effects (PESSOA et al., 2004). The fraction of $A$. oncocalyx and onco A in different lineages of cells, especially in tumor cell lines, had a similar effect when compared to DXR (PESSOA et al., 2000, 2003, 2004)increasing the risk for the development of a second cancer, particularly acute leukemia. The association between therapeutic and genotoxic properties of oncocalyxone A (Onco A. DXR and onco A have been shown to exhibit cytotoxicity in the G, G1/S, and S phases of cell division; however, only DXR exhibited genotoxicity in these cells (PESSOA et al., 2003)increasing the risk for the development of a second cancer, particularly acute leukemia. The association between therapeutic and genotoxic properties of oncocalyxone A (Onco A. This genotoxicity caused by DXR could explain the decrease in the percent of morphologically intact follicles and antrum formation in this study.

The percent of TUNEL-positive follicles (TPF) was higher $(\mathrm{P}<0.05)$ for the DXR treatment when compared to non-cultured control. No difference $(\mathrm{P}>0.05)$ in the percent of TPF among the other treatments. The number of PCNA-positive granulosa cells were lower $(\mathrm{P}<0.05)$ for the DXR treatment when compared to the other treatments (control, DMSO, A. oncocalyx, and onco A) (Table 4). In addition, DXR was the only treatment that decreased $(\mathrm{P}<0.05)$ the relative BAX:BCL2 mRNA ratio (Figure 2). More studies are therefore needed to discern the mechanism of action of both drugs. Recent studies have revealed that DXR induces ovarian toxicity, which was observed by a reduction in the ovulation rate and the size of the ovary (OKTEM; OKTAY, 2007; BAR-JOSEPH et al., 2010; BEN-AHARON et al., 2010). DXR elicits apoptosis by various mechanisms in a variety of cells. It can be accumulated in both the nucleus and mitochondria and induces chromosomal destruction by inhibiting topoisomerase-II (TOKARSKASCHLATTNER et al., 2006). DXR can also interfere with mitochondrial function and initiate an intrinsic pathway of apoptosis by reducing the mitochondrial membrane potential and releasing cytochrome $\mathrm{C}$ (BAR-JOSEPH et al., 2010). 
Figure 1. Isolated secondary follicles before (a) and after 7 days of culture in $\alpha-\mathrm{MEM}^{+}$alone (cultured-control) (b) or supplemented with DMSO (c), DXR (d), A. oncocalyx (e) and onco A (f). Oocytes after in vitro maturation in $\mathrm{TCM}_{199}$ (control) (g) or supplemented with DMSO (h), DXR (i), A. oncocalyx (j) or onco A (k).

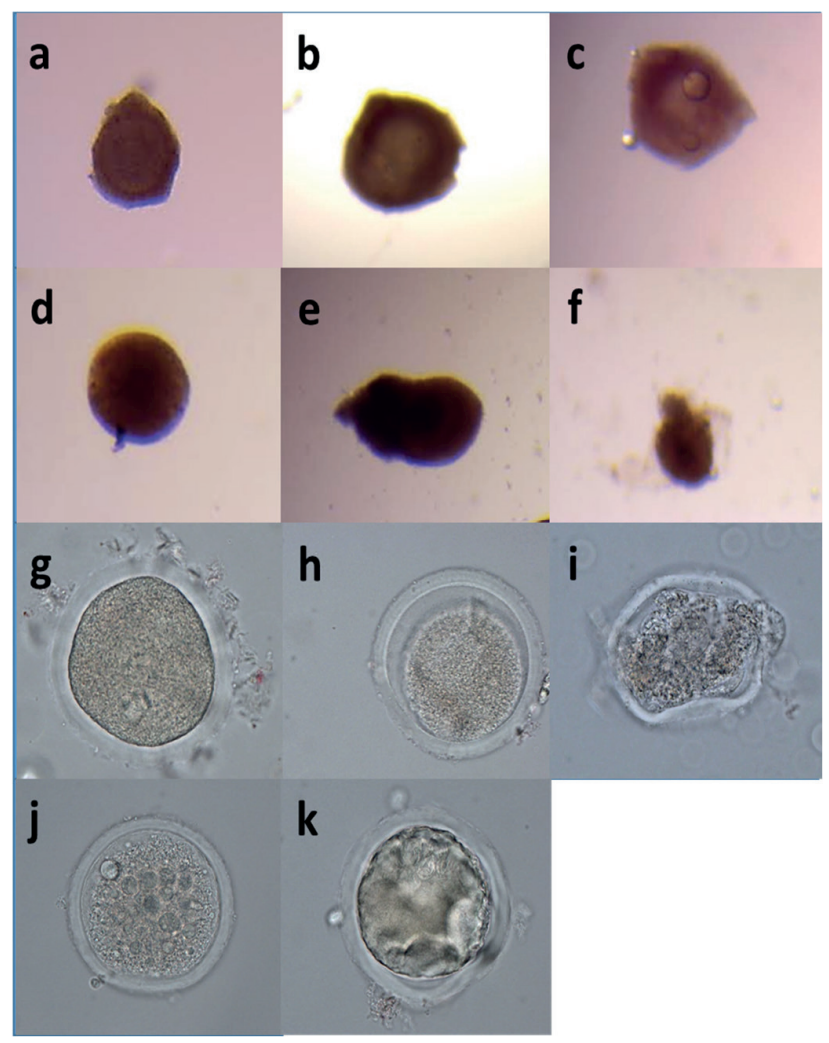

Table 2. Percentage of morphologically intact secondary follicles, and antrum formation after in vitro culture for 7 days in $\alpha-\mathrm{MEM}^{+}$(control) or supplemented with DMSO, DXR, A. oncocalyx or onco A.

\begin{tabular}{lcc}
\hline Treatments $(\mathrm{n})$ & \% Morphologically intact follicles & \% Antrum formation \\
\hline Control $(\mathrm{n}=67)$ & $92.54(62 / 67) \mathrm{A}$ & $59.70(40 / 67) \mathrm{A}$ \\
DMSO $(\mathrm{n}=58)$ & $89.66(52 / 58) \mathrm{A}$ & $50.00(29 / 58) \mathrm{A}$ \\
DXR $(\mathrm{n}=59)$ & $55.93(33 / 59) \mathrm{B}$ & $16.95(10 / 59) \mathrm{B}$ \\
A. oncocalyx $(\mathrm{n}=59)$ & $86.44(51 / 59) \mathrm{A}$ & $57.63(34 / 59) \mathrm{A}$ \\
Onco A $(\mathrm{n}=58)$ & $84.48(49 / 58) \mathrm{A}$ & $55.17(32 / 58) \mathrm{A}$ \\
\hline
\end{tabular}

A,B Distinct capital letters represent significant differences among experimental treatments $(\mathrm{P}<0.05)$.

$\mathrm{n}$ Total number of analyzed follicles per treatment.

Table 3. Follicular diameter (on day 0 and 7) and growth rate (mean \pm SEM) of isolated secondary follicles after in vitro culture in $\alpha-\mathrm{MEM}^{+}$(control) or supplemented with DMSO, DXR, A. oncocalyx or onco A

\begin{tabular}{lccc}
\hline Treatments & D0 & D7 & Growth rate \\
\hline Control & $156.87 \pm 39.13 \mathrm{Ab}$ & $184.41 \pm 53.16 \mathrm{Aa}$ & $4.19 \pm 6.12 \mathrm{~A}$ \\
DMSO & $155.26 \pm 34.43 \mathrm{Ab}$ & $177.99 \pm 53.41 \mathrm{Aa}$ & $2.96 \pm 6.87 \mathrm{~A}$ \\
DXR & $151.59 \pm 38.55 \mathrm{Aa}$ & $148.12 \pm 39.36 \mathrm{Ba}$ & $-0.49 \pm 3.80 \mathrm{~B}$ \\
A. oncocalyx & $161.44 \pm 38.24 \mathrm{Ab}$ & $188.87 \pm 52.56 \mathrm{Aa}$ & $4.03 \pm 6.62 \mathrm{~A}$ \\
Onco A & $165.20 \pm 44.77 \mathrm{Aa}$ & $178.05 \pm 51.22 \mathrm{Aa}$ & $1.85 \pm 6.79 \mathrm{~A}$ \\
\hline
\end{tabular}

$\overline{\mathrm{A}, \mathrm{B}}$ Distinct capital letters represent significant differences among treatments within the same day of culture. ${ }^{\mathrm{a}, \mathrm{b}}$ Different lowercase letters represent significant differences between days of culture within the same treatment. $(\mathrm{P}<0.05)$. 
Table 4. PCNA test and TUNEL assay of non-cultured or in vitro cultured isolated secondary follicles for 7 days in $\alpha-\mathrm{MEM}^{+}$(control) or supplemented with DMSO, DXR, A. oncocalyx or onco A.

\begin{tabular}{lcc}
\hline Treatments & PCNA & TUNEL \\
\hline Non-cultured control & $87.45 \pm 7.32 \mathrm{~A}$ & $16.67 \%(1 / 6) \mathrm{B}$ \\
Control & $89.72 \pm 8.83 \mathrm{~A}$ & $33.33 \%(2 / 6) \mathrm{AB}$ \\
DMSO & $94.20 \pm 6.00 \mathrm{~A}$ & $33.33 \%(2 / 6) \mathrm{AB}$ \\
DXR & $16.54 \pm 9.70 \mathrm{~B}$ & $100.00 \%(4 / 4) \mathrm{A}$ \\
A. oncocalyx & $93.20 \pm 4.51 \mathrm{~A}$ & $60.00 \%(3 / 5) \mathrm{AB}$ \\
Onco A & $94.07 \pm 6.71 \mathrm{~A}$ & $50.00 \%(3 / 6) \mathrm{AB}$ \\
\hline
\end{tabular}

Distinct capital letters represent significant differences among experimental treatments $(\mathrm{P}<0.05)$.

Figure 2. Relative mean ( \pm SEM) of BAX:BCL2 mRNA ratio in cultured isolated secondary follicles for 7 days in $\alpha-\mathrm{MEM}^{+}$alone (cultured-control) or supplemented with DMSO, DXR, A. oncocalyx and onco A. Different letters denote significant differences $(\mathrm{P}<0.05)$.

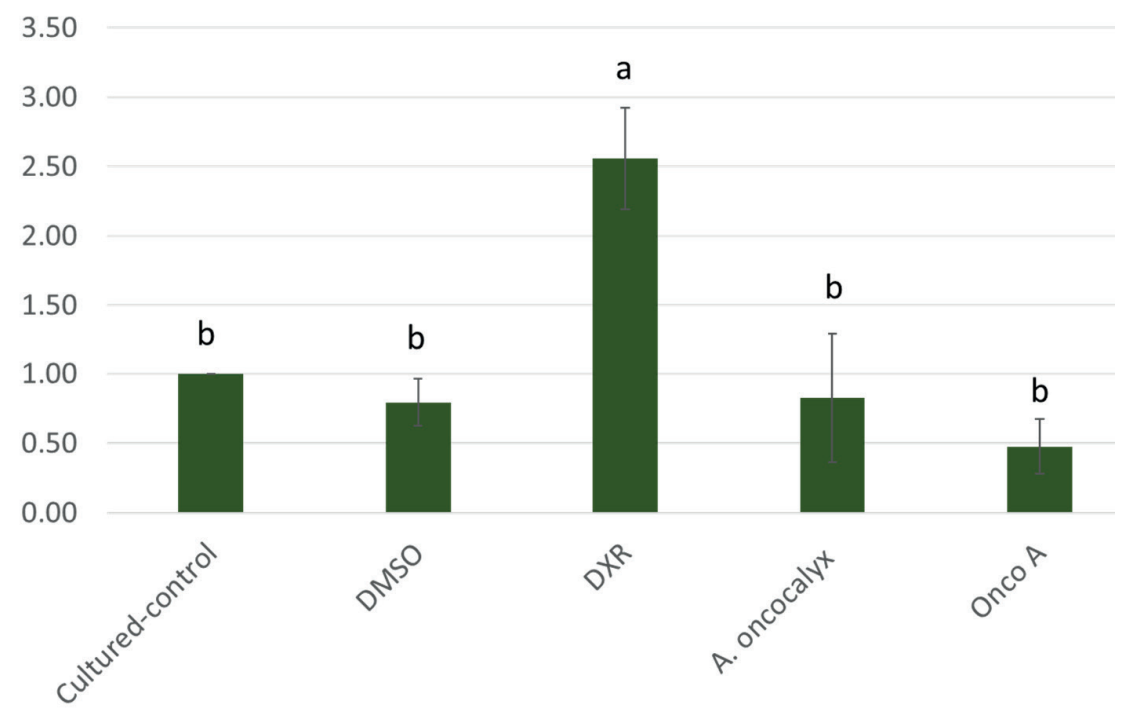

In this study, a decrease $(\mathrm{P}<0.05)$ in the percent of viable oocytes when they were treated with DXR, A. oncocalyx, and onco A. The percent of non-alive oocytes was significantly higher $(\mathrm{P}<0.05)$ in the onco A treatment than in the DXR and A. oncocalyx treatments. The opposite was observed for the percent of alive oocytes with abnormal chromatin configuration. Compared to its vehicle (DMSO), onco A and DXR treatments reduced $(\mathrm{P}<0.05)$ the percent of oocyte meiotic resumption, but they were similar $(\mathrm{P}>0.05)$ to that in the control treatment. In addition, the MII rates were similar $(\mathrm{P}>0.05)$ among the treatments (Table 5). The IVM culture system used in the present study was adequate to investigate the impact of the studied drugs (DXR, A. oncocalyx, and onco A) on IVM. The control medium used ensured the maintenance of appropriate rates of viability $(90.67 \%)$ and meiotic resumption $(92.65 \%)$. These data are in agreement with those of our previous studies reporting the IVM of caprine COCs using the same culture medium. In this study, DXR, A. oncocalyx, and onco A negatively affected oocyte viability (Figure 1). It is known that DXR can induce cellular apoptosis. Moreover, a study evaluating different concentrations ( 1 to $100 \mu \mathrm{g} / \mathrm{mL}$ ) of a quinone fraction of $A$. oncocalyx (containing $80 \%$ of onco A) in sea urchin eggs reported that the cleavage of eggs was inhibited in a concentration- 
dependent manner, and, when a concentration of 30 $\mu \mathrm{g} / \mathrm{mL}$ was used, it caused total destruction (100\%) of the embryos (COSTA-LOTUFO et al., 2002).

Only DXR and onco A caused a harmful effect on meiotic resumption. This finding can be attributed to the higher sensitivity of the COCs to a toxic compound. The presence of alive oocytes with abnormal chromatin configuration implies the occurrence of apoptosis (BAR-JOSEPH et al., 2010). Moreover, only DXR and A. oncocalyx exhibited an increase in oocytes with abnormal chromatin configuration, showing less harmful effect of onco A. This result may be due to the impurity of the fraction of $A$. oncocalyx that contains $80 \%$ of onco A (FERREIRA et al., 2004), and 20\% of other substances that may be more toxic than onco A alone. In addition, Pessoa et al. (PESSOA et al., 2003)increasing the risk for the development of a second cancer, particularly acute leukemia. The association between therapeutic and genotoxic properties of oncocalyxone A (Onco A showed that, although onco A and DXR have cytotoxicity in lymphocytes, only DXR present genotoxicity, proving to be more toxic. It is important to highlight that the DMSO treatment (i.e., the vehicle used for the dilution of DXR, A. oncocalyx, and onco A) was similar to the $\alpha-\mathrm{MEM}^{+}$cultured control. This result shows that DMSO alone was not responsible for the negative effect of the tested drugs in any of the studied end-points.

Table 5. Viable and non-viable oocytes rates, germinal vesicle (GV), meiotic resumption and metaphase II (MII) rates, after in vitro maturation in TCM199+ (control) or supplemented with DMSO, DXR, A. oncocalyx or onco A of COCs recovered from antral follicles.

\begin{tabular}{|c|c|c|c|c|c|c|c|c|c|c|}
\hline \multirow{3}{*}{ Treatments } & \multicolumn{4}{|c|}{ NON-VIABLE OOCYTES } & \multirow{2}{*}{$\begin{array}{l}\text { VIABLE } \\
\text { OOCYTES }\end{array}$} & \multicolumn{5}{|c|}{ MATURATION RATES OF VIABLE OOCYTES } \\
\hline & TOTAL & Non-alive & Alive \# & TOTAL & & GV & $\frac{\text { Meiotic }}{\text { Resumption* }}$ & GVBD & MI & MII \\
\hline & (n) & $\%$ & $\%$ & $\%$ & $\%$ & $\%$ & $\%$ & $\%$ & $\%$ & $\%$ \\
\hline Control & 75 & $\begin{array}{c}57.14 \mathrm{AB} \\
(4 / 7)\end{array}$ & $\begin{array}{c}42.86 \mathrm{AB} \\
(3 / 7)\end{array}$ & $\begin{array}{l}9.33 \mathrm{~B} \\
(7 / 75)\end{array}$ & $\begin{array}{l}90.67 \mathrm{~A} \\
(68 / 75)\end{array}$ & $\begin{array}{c}7.35 \mathrm{AB} \\
(5 / 68)\end{array}$ & $\begin{array}{c}92.65 \mathrm{AB} \\
(63 / 68)\end{array}$ & $\begin{array}{l}5.88 \mathrm{~A} \\
(4 / 68)\end{array}$ & $\begin{array}{l}29.41 \mathrm{~A} \\
(20 / 68)\end{array}$ & $\begin{array}{l}57.35 \mathrm{~A} \\
(39 / 68)\end{array}$ \\
\hline DMSO & 84 & $\begin{array}{c}69.23 \mathrm{AB} \\
(9 / 13)\end{array}$ & $\begin{array}{c}30.77 \mathrm{AB} \\
(4 / 13)\end{array}$ & $\begin{array}{l}15.48 \text { B } \\
(13 / 84)\end{array}$ & $\begin{array}{l}84.52 \mathrm{~A} \\
(71 / 84)\end{array}$ & $\begin{array}{l}4.23 \mathrm{~B} \\
(3 / 71)\end{array}$ & $\begin{array}{c}95.77 \mathrm{~A} \\
(68 / 71)\end{array}$ & $\begin{array}{l}8.45 \mathrm{~A} \\
(6 / 71)\end{array}$ & $\begin{array}{l}30.99 \mathrm{~A} \\
(22 / 71)\end{array}$ & $\begin{array}{l}56.34 \mathrm{~A} \\
(40 / 71)\end{array}$ \\
\hline DXR & 77 & $\begin{array}{l}46.43 \mathrm{~B} \\
(13 / 28)\end{array}$ & $\begin{array}{l}53.57 \mathrm{~A} \\
(15 / 28)\end{array}$ & $\begin{array}{l}36.36 \mathrm{~A} \\
(28 / 77)\end{array}$ & $\begin{array}{l}63.64 \text { B } \\
(49 / 77)\end{array}$ & $\begin{array}{c}14.29 \mathrm{~A} \\
(7 / 49)\end{array}$ & $\begin{array}{l}85.71 \mathrm{~B} \\
(42 / 49)\end{array}$ & $\begin{array}{l}2.04 \mathrm{~A} \\
(1 / 49)\end{array}$ & $\begin{array}{l}36.73 \mathrm{~A} \\
(18 / 49)\end{array}$ & $\begin{array}{l}46.94 \mathrm{~A} \\
(23 / 49)\end{array}$ \\
\hline A. oncocalyx & 77 & $\begin{array}{l}44.12 \text { B } \\
(15 / 34)\end{array}$ & $\begin{array}{l}55.88 \mathrm{~A} \\
(19 / 34)\end{array}$ & $\begin{array}{l}44.16 \mathrm{~A} \\
(34 / 77)\end{array}$ & $\begin{array}{l}55.84 \mathrm{~B} \\
(43 / 77)\end{array}$ & $\begin{array}{c}13.95 \mathrm{AB} \\
(6 / 43)\end{array}$ & $\begin{array}{c}86.05 \mathrm{AB} \\
(37 / 43)\end{array}$ & $\begin{array}{l}2.33 \mathrm{~A} \\
(1 / 43)\end{array}$ & $\begin{array}{l}34.88 \mathrm{~A} \\
(15 / 43)\end{array}$ & $\begin{array}{l}48.84 \mathrm{~A} \\
(21 / 43)\end{array}$ \\
\hline Onco A & 86 & $\begin{array}{l}71.79 \mathrm{~A} \\
(28 / 39)\end{array}$ & $\begin{array}{l}28.21 \mathrm{~B} \\
(11 / 39)\end{array}$ & $\begin{array}{l}45.35 \mathrm{~A} \\
(39 / 86)\end{array}$ & $\begin{array}{l}54.65 \mathrm{~B} \\
(47 / 86)\end{array}$ & $\begin{array}{c}17.02 \mathrm{~A} \\
(8 / 47)\end{array}$ & $\begin{array}{l}82.98 \text { B } \\
(39 / 47)\end{array}$ & $\begin{array}{l}4.26 \mathrm{~A} \\
(2 / 47)\end{array}$ & $\begin{array}{l}31.91 \mathrm{~A} \\
(15 / 47)\end{array}$ & $\begin{array}{l}46.81 \mathrm{~A} \\
(22 / 47)\end{array}$ \\
\hline
\end{tabular}

\section{Conclusions}

In conclusion, under our culture conditions, $A$. oncocalyx and onco A did not have a toxic effect on the isolated secondary follicles and maturation rates on in vitro-matured COCs; however, these drugs affect the oocyte viability after IVM. In addition, the less harmful effect of onco A than DXR on caprine secondary follicle survival and oocytes with normal chromatin configuration may encourage future studies involving the use of this drug for cancer treatment in women. 


\section{Acknowledgments}

This research was financially supported by CNPq, CAPES and FUNCAP. The authors thank Francisco Leo Aguiar, Victor Macedo Paes, Denise Damasceno Guerreiro, Renato Félix da Silva and Naiza Arcângela Ribeiro de Sá for assistance with this study.

\section{References}

ARAÚJO, V. R.; SILVA, G. M.; DUARTE, A. B. G.; MAGALHÃES, D. M.; ALMEIDA, A. P. Vascular endothelial growth factor-A165 (VEGF-A165) stimulates the in vitro development and oocyte competence of goat preantral follicles. Cell and Tissue Research, Fortaleza, v. 165 , p. 273-281, 2011.

BAR-JOSEPH, H.; BEN-AHARON, I.; RIZEL, S.; STEMMER, S. M.; TZABARI, M.; SHALGI, R. Doxorubicin-induced apoptosis in germinal vesicle $(\mathrm{GV})$ oocytes. Reproductive Toxicology, Elmsford, v. 30, n. 4, p. 566-72, dez. 2010.

BEN-AHARON, I.; BAR-JOSEPH, H.; TZARFATY, G.; KUCHINSKY, L.; RIZEL, S.; STEMMER, S. M.; SHALGI, R. Doxorubicin-induced ovarian toxicity. Reproductive Biology and Endocrinology: $R B \& E$, Fortaleza, v. 8, p. 20-22, jan. 2010.

BRAGA, R. Plantas do nordeste, especialmente do Ceará. 3. ed. [S.1: s.n.], 1976.

CHOW, W.-H.; DONG, L. M.; DEVESA, S. S. Epidemiology and risk factors for kidney cancer. Nature Reviews Urology, v. 7, n. 5, p. 245-257, 2010.

COSTA-LOTUFO, L. V.; FERREIRA, M. A. D.; LEMOS, T. L. G.; PESSOA, O. D. L.; VIANA, G. S. B.; CUNHA, G. M. Toxicity to sea urchin egg development of the quinone fraction obtained from Auxemma oncocalyx. Brazilian Journal of Medical and Biological Research, Ribeirão Preto, v. 35, n. 8, p. 927-930, 2002.

CRAGG, G. M.; GROTHAUS, P. G.; NEWMAN, D. J. New horizons for old drugs and drug leads. Journal of Natural Products, v. 77, p. 703-723, 2014.

CRAGG, G. M.; NEWMAN, D. J. Plants as a source of anti-cancer agents. Journal of Ethnopharmacology, v. 100, n. 1-2, p. 72-9, 2005.

DUARTE, A. B. G.; ARAÚJO, V. R.; CHAVES, R. N.; SILVA, G. M. da; LUZ, V. B.; THOMAS, K. H.; MAGALHÃES-PADILHA, D. M.; ALMEIDA, A. P.; LOBO, C. H.; CAMPELLO, C. C.; FIGUEIREDO, J.
R. Insulin-like growth factor II ( IGF-II ) and follicle stimulating hormone ( FSH ) combinations can improve the in vitro development of grown oocytes enclosed in caprine preantral follicles. Growth Hormone \& IGF Research, v. 23, n. 1-2, p. 37-44, 2013.

FERREIRA, M. A. D.; NUNES, O. D. R. H.; FONTENELE, J. B.; PESSOA, O. D. L.; LEMOS, T. L. G.; VIANA, G. S. Analgesic and anti-inflammatory activities of a fraction rich in oncocalyxone $\mathrm{A}$ isolated from Auxemma oncocalyx. Phytomedicine: International Journal of Phytotherapy and Phytopharmacology, v. 11, n. 4, p. 315-322, 2004.

FERREIRA, M. A. D.; NUNES, O. D. R. H.; LEAL, L. K. A. M.; PESSOA, O. D. L.; LEMOS, T. L. G. de; VIANA, G. S. D. B. Antioxidant effects in the quinone fraction from Auxemma oncocalyx TAUB. Biological \& Pharmaceutical Bulletin, Fortaleza, v. 26, n. 5, p. 595599, 2003.

FIGUEIREDO, J. R. de; CELESTINO, J. J. D. H.; FAUSTINO, L. R.; RODRIGUES, A. P. R. In vitro culture of caprine preantral follicles: advances, limitations and prospects. Small Ruminant Research, Amsterdam, v. 98, n. 1-3, p. 192-195, jun. 2011.

GRAHAM, J. G.; QUINN, M. L.; FABRICANT, D. S.; FARNSWORTH, N. R. Plants used against cancer - an extension of the work of Jonathan Hartwell. Journal of Ethnopharmacology, v. 73, p. 347-377, 2000.

LEYVA, A.; PESSOA, O.; BOOGAERDT, F.; SOKAROSKI, R.; LEMOS, T. G.; WETMORE, L. A.; HURUTA, R. R.; MORAES, M. O. Oncocalyxones A and C, 1,4-antracenediones from Auxemma oncocalyx: comparison with anticancer 1,9-anthracenediones. Anticancer Research, Fortaleza, v. 20, n. 2A, p. 10291032, 2000.

LINO, C. S.; PESSOA, O. D. L.; LEMOS, T. L. C.; VIANA, G. S. B. Estudo da atividade analgésica e antiedematogênica do extrato hidroalcoólico de Auxemma oncocalyx e oncocalyxona A. In: SIMPÓSIO DE PLANTAS MEDICINAIS DO BRASIL, 1996, Florianópolis. Anais... Florianopolis, 1996. p. 95.

LIVAK, K. J.; SCHMITTGEN, T. D. Analysis of relative gene expression data using real- time quantitative PCR and the 2 -DDCT method. Methods, v. 408, n. 25, p. 402408, 2001.

MAILER, K.; PETIRING, D. H. Inhibition of oxidative phosphorylation in tumor cells and mitochondria by daunomycin and adriamycin. Biochemical Pharmacology, v. 25, p. 6-10, 1976. 
NEWMAN, D. J.; CRAGG, G. M.; SNADER, K. M. Natural products as sources of new drugs over the period 1981 - 2002. Journal of Natural Products, v. 66, p. 10221037,2003 .

OKTEM, O.; OKTAY, K. Quantitative assessment of the impact of chemotherapy on ovarian follicle reserve and stromal function. Cancer, v. 110, n. 10, p. 2222-2229, 2007.

PESSOA, C.; LEMOS, T. L. G.; PESSOA, O. D. L.; MORAES, M. O.; COSTA-LOTUFO, L. V.; LEYVA, A. Cytotoxicity of derivatives of oncocalyxone A from Auxemma oncocalyx Taub. ARKIVOC, Fortaleza, v. 6, p. 89-94, 2004.

PESSOA, C.; MENDES, C. S.; PESSOA, L. O.; SABINO, S. H.; LEMOS, T.; MORAES, M. O. Avaliação da atividade antitumoral de Auxemma oncocalyx Taub. (Pau Branco). In: ANNUAL MEETING OF THE FEDERAÇÃO DE SOCIEDADES DE BIOLOGIA EXPERIMENTAL, 7., 1992, Caxambu. Anais... Caxambu: 1992. p. 168.

PESSOA, C.; SILVEIRA, E. R.; LEMOS, T. L. G.; WETMORE, L. A.; MORAES, M. O.; LEYVA, A. Antiproliferative effects of compounds derived from plants of Northeast Brazil. Phytotherapy Research, Malden, v. 14, p. 187-191, 2000.
PESSOA, C.; VIEIRA, F. M. A. C.; LEMOS, T. G.; MORAES, M. O.; LIMA, P. D. L.; RABENHORST, S. H. B.; LEYVA, A.; BURBANO, R. R. Oncocalyxone A from Auxemma oncocalyx lacks genotoxic activity in phytohemagglutinin-stimulated lymphocytes. Teratogenesis, Carcinogenesis, and Mutagenesis, Fortaleza, v. 1, p. 215-220, jan. 2003.

PESSOA, O. D. L.; LEMOS, T. L. G.; SILVEIRA, E. R.; BRAZ-FILHO, R. Novel cordiachromes isolated from Auxemma oncocalyx. Natural Product Research, Fortaleza, v. 2, p. 145-150, 1993.

STEFANSDOTTIR, A.; FOWLER, P. A.; POWLESGLOVER, N.; ANDERSON, R. A.; SPEARS, N. Use of ovary culture techniques in reproductive toxicology. Reproductive Toxicology, v. 49, p. 117-135, 2014.

TOKARSKA-SCHLATTNER, M.; ZAUGG, M.; ZUPPINGER, C.; WALLIMANN, T.; SCHLATTNER, U. New insights into doxorubicin-induced cardiotoxicity: the critical role of cellular energetics. Journal of Molecular and Cellular Cardiology, v. 41, p. 389-405, 2006. 
